\title{
The Relations of Structuration in the BPJS Health Program and the Changing of Health Behavior
}

\author{
RB. Soemanto, T.A. Gutama
}

Department of Sociology, Universitas Sebelas Maret, Surakarta, Indonesia

\section{ABSTRACT}

Background: The BPJS Health Program supports the improvement of public health in Indonesia. BPJS stands for Social Insurance Administration Organization. It administers the Indonesian national health insurance for short. BPJS health and BPJS employment programs are the version of BPJS.. This study aimed to understand the relations of structuration of the BPJS Health Program and changing of health behavior in $\mathrm{Su}-$ rakarta Indonesia.

Subjects and Method: A qualitative study was carried out by phenomenological approach. The BPJS participants' program was primary informants. The key informants were doctors, nurses, midwives, and other services officers of the community health center (Puskesmas), hospital, and Health BPJS office. The supported informants consisting of the Health Office services, the Population, and Civil Registration Offices, the Communication and Information Services, the Social Services of the Local Government of Surakarta Municipality. Depth interviews and the focus group discussion (FGD) technique were applied to gather data. Data analysis technique using interpretative phenomenology, and theory of structuration from Anthony Giddens for explaining the data.

Results: Interactional practices in the health service processes produce attitudes, awareness of health services provided. It improves the healthy behavior of the BPJS participants. Rules and regulations of the health center and referenced hospitals accepted and followed by the participant. Doctors and other health care providers work professionally to accommodate patients' needs. The participants reproduce duality structure and roles in the health services delivery processes. The participants as agents develop structuration; where agents respond to agency of structure of the health services, and vice versa. Patients and health services providers have mutually reinforced roles and benefits. In the course of space and time, the actions of the participants are recurring.

Conclusion: Collaboration was developed between the BPJS Office with Puskesmas and hospitals. It brings closer to social relations between patients and health care providers. It was constructed due to understanding and obedience of the participants to the rules, in the forms of procedural rules and doctors' medicalization.

Keywords: relations, structuration, BPJS Health Program, health behavior, change

\section{Correspondence:}

RB. Soemanto. Department of Sociology, Universitas Sebelas Maret. Jl. Ir. Sutami 36A, Surakarta 57126, Central Java, Indonesia. Email: Soemanto_rb@yahoo.com, rbsoemanto@gmail.com.

Cite this as:

Soemanto RB, Gutama TA (2020). The Relations of Structuration in the BPJS Health Program and the Changing of Health Behavior. J Health Policy Manage. 5(2): 121-126. https://doi.org/10.26911/thejhpm.2020.05.02.04 Journal of Health Policy and Management is licensed under a Creative Commons Attribution-Non Commercial-Share Alike 4.0 International License.

\section{BACKGROUND}

The Ministry of Health develops the National Social Health Insurance (JKN) Program by applying KIS (Healthy Indonesia Card Systems). BPJS is The Social Health Security Service who manage the system operations.
The operational system based on the principle of Gotong Royong, as a Mutually Cooperation of people to achieve a certain goals (it is constructed by, for and with the peoples of a community. 
The implementation of the BPJS Health program in Surakarta based on the Law of National Health Insurance Number 40, 2014; The Presidential Regulation Number 82, 2018, and the Presidential Instructions Number 8, 2017.These regulations encourage The Local Government Policy, especially the Innovative Policy of Pro-active community Services of City Mayor of Surakarta that socalled "Sapu Kuwat Program". It supports the Health BPJS Program operation in Surakarta.

A team work inter-sectorial of Surakarta had been developed by organizing theroles and functions of the communication and Information Office, Social Affair Service, Population and Civil Registry Service, Health Affair Office, Manpower Office, and BPJS Office. It is coordinated by the Head of the Communication and Information Office to integrate tasks and functions of those institutions to support development of the BPJS health service system. Each institution takes part according to the tasks and functions relevant to the development of BPJS health services. The socialization and promotion of BPJS health program to the community is carried out by the Social Service, Manpower Office, Health Office, and Health Center.

The increasing number of BPJS health participants is a description of the condition of public health status. The greater the number of participants will guarantee to increase the public health status. The role of these institutions can support to strengthening the social relations of BPJS participants and the structure of health services, and also improving the quality of health services for the community of Surakarta. The Government facilitates health service centers of hospitals, public health centers (Puskesmas), and services of family doctors. To support the implementation of BPJS Health service system.

The BPJS system supports the mission and objectives to improve community's health status of the people of Indonesia. Since the BPJS system has been executed, community's participation in the health services program is low. The distribution of health care facilities has not been equally distributed, and the availability of health service tools has not all been adequate for public health service needs. Mostly rural communities less attention to participate to utilize health services than the urban communities.

\section{Table 1. Distribution of the NationalBPJS Health Program Participants, 2017}

\begin{tabular}{llll}
\hline No & Group & Total (Rp) & Percentage (\%) \\
\hline 1 & The National Budget based & $92,380,352$ & 49.2 \\
2 & Regional budget based & $20,305,273$ & 10.8 \\
3 & Public employees service & $13,851,821$ & 7.4 \\
4 & Army members & $1,574,303$ & 0.8 \\
5 & Police officers & $1,248,544$ & 0.7 \\
6 & National \& public officers company & $1,480,978$ & 0.8 \\
7 & Regional \& public officers company & 178,206 & 0.01 \\
8 & Private enterprise employee & $26,557,190$ & 14.1 \\
9 & Personnel insurance & $25,397,828$ & 13.5 \\
10 & Others & $5,008,454$ & 2.6 \\
TOTAL & & $\mathbf{1 8 7 , 9 8 2 , 9 4 9}$ & $\mathbf{1 0 0}$ \\
\hline
\end{tabular}

Source: BPJS Central Java and Special Region of Yogyakarta, 2017

Number of the BPJS program participants in Central Java and Yogyakarta was 27,613,423 persons (1 December2017), and the number of the JKN Program Participants was
187,982,949 persons (31 December 2017). Previous study results show that $52 \%$ of the people were satisfied with the health service provision at Permata Medika Hospital, 
Semarang. The reasons were efficient and precise in health services, the procedure were not complicated (Ulinuha, 2014). The informants over the age of 15 expressed satisfaction with the health services of the Pekanbaru community Health Center. The reasons were that physical facilities well maintained, medical expenses were free (Septia et al., 2015).

However, $65 \%$ of respondents did not visit yet Puskesmas services in Mapanget Sub-district, Menado (Rumengan et al., 2015). There were73\% of respondents disagreeing on the 5 variables of service quality (Tangible, Responsiveness, Reliability, Assurance, and Empathy) according to users who come to the physician services at Hermina Bogor Hospital (Putri et al., 2017).

The development of public health services requires knowledge, awareness, response of community and their health behavior. It also requires health services providers and supports from government policies and its programs implementation as well as the role of the private hospitals' health services providers. Status, roles, relations, regulations (norms), authorities, and social practices of the BPJS participants and also the influence of effective work of the BPJS health services; all of these will guarantee to the achievement of the stated goals.

The question is: "How does the relation of structuration of the BPJS Health Program and changing of health behavior in Surakarta Indonesia?".

\section{THEORETICAL REVIEW}

The theoretical approach to answer study questions requires sociological theory of the relationship between structure and function in organizations, and the theory of symbolic interactionism. This study applies the structuration theory of Anthony Giddens.

Elements of Structuration theory include rationalization of daily habits towards efficient social life in the form of actions or activities, motivation and social context, which have two basic factors. Firstly, discursive awareness (description of actions in words), and secondly, practical awareness as actions deemed correct by the actors. The structural theory emphasizes practical awareness that drives action and behavior of actors and their activities.

The actors include what is actually done in any time and places. Activities describe the role of the individual actor as the actual experiences. Events and activities involve the actions of actors that produce structure. Activities are not the goal, because action cannot always achieve the desired goal.

Solid Power and authority of actors determine the actor to choose or reject behavioral changes. Power logically precedes subjectivity because action involves the power of behavioral changing. Structural theory pays attention to the power of the actors and their actions.

Dialectical relationships among actors and structural institutions influence the development of relationships as a whole process. Giddens calls the relation between agents and structures as dual-action that it requires structure, and vice versa, structure requires individual social action. Repeated social actions or practices through the activities of actors will create reflexive awareness and structure. Giddens' structuration theory emphasizes that the dialectical process creates social practice, structure and reflexive awareness.

Basically structuration theory emphasizes: (1) the order of social institutions that cross space and time (i.e symbolic order, political, economic and legal institutions; (2) emphasizing changes in social institutions that cross space and time; (3) the intervention of institutional leaders change the pattern of social relations. The structure, system and duality relation between actors 
and institutional structure explain that the structure is determined by rules and resources through the activities of human actors. Structural shape determines social life or community through actions, activities, and social practices.

Structuration theory will explain the findings to answer the study question: "how does the relation of structuration of the BPJS Health Program and changing of health behavior in Surakarta Indonesia?"

Changing of the health behavioral participants may influence the rational decision, increasing awareness, decisional processes, and the relations between agents or the subjects and institutional structures or the systems following the rules or regulation (agency). These improve patterns behaviors and affect the increasing degree of public health.

\section{SUBJECTS AND METHOD}

\section{Study Design}

This study was designed in qualitative phenomenological approach. This study reveals that truth found in the experience and practice of daily lives of community. The meaning of experience and practice is discovered in institutions or actors' experience reflection. Practices and actions are extracted from relationships, integration of actors and social structures based on inter subjective actor's relationships, and scientific evidence assessment (Kuswarno, 2009).

\section{Study Subjects}

Subjects of the study were the participants of the Health BPJS Program in Surakarta. There are 3 primary informant sources, i.e. key informants namely the persons operating the Surakarta BPJS Office which provide services in Surakarta, The Kasih Ibu, and Brayat Minulya private referenced hospital. The main informants are BPJS participants selected according to socio-economic characteristics. The Supporting informants is the Head of
Public Service Office such as Social Affair Service, Population and Civil Registry Service, and Health Affairs Service, The Head of Communication and Information Affair Service.

\section{Study Instrument}

The data collection technique uses non-participation observations on community helath center and hospital who was practicing to serves health BPJS participants. In-depth interview techniques were carried out on all groups of informants, i.e. the key, main and the supporter informants.

\section{Data Analysis}

Analysis and processing data is done by reading, remembering, reviewing data, reflecting, and describing data, classifying, interpreting, visualizing and presenting data (Creswell, in Kuswarno, 2009). Data triangulation uses data sources and data collection techniques.

\section{Participants of the Health BPJS programs in}

Surakarta consist of Contribution Aid Recipients (PBI), personnel insurance, Companies, civil servant (ASN), members of the Indonesian Armed Forces (TNI) and member of the Indonesian National Police (POLRI).

The number of participants of the BPJS program was about $97.5 \%(563,814)$ in December 2018, and was 98.2\%) in January 2019. During one month the number of participants increases $0.7 \%$. The biggest number of participants is the PBI $(159,445)$ in 2018, and 161,352 people in 2019.

The participations are those who have the BPJS Health Card. The operation of the program has started since 2014 which continually operates until now, however, there is no one dropped out, except they die. The cardholders of program registered at the BPJS Surakarta Office, are entitled to receive health services from the Puskesmas, family doctors, and hospitals in Surakarta. 
Mostly PBI groups of participants had come to seek treatment specifically to the Community Health Center, they received outpatient medication. Those participants who visit the Puskemas complies with procedural rule or regulations such as doing registration, choosing medical doctors, following a line of the doctors' services and in receiving drugs

Referral to the Hospital is given by the Puskesmas and the family doctor to get the hospital health services. They follow the referral system based on definitive regulation. Participants who consult to the Puskesmas and hospitals medical doctors to receive medication services, they could dialogue with doctors. Participants feel satisfied with the doctor's attention, and they obey the doctors' advice, instructions and they return to consult the doctors following advice and recommendation.

\section{DISCUSSION}

Comparing to previous patients' healthbehavior, the present behavior shows the changing their health behavior. The former patient's behavior mostly differs from the present health behavior. In addition, the health service system of the Puskesmas and the Hospital is felt to be better and beneficial for process healing, because participants or patients obey the doctor's orders and use regularly the medicines.

The patients, medical doctors, other health servants, and the administrative servants of the Puskesmas, and of the Hospital carry out duties by obeying procedures and regulation in the health provisional treatment services. These relationships occur because the patients need medication and advice; and the doctors like accommodate them. They need each other in the process providing health services in the Puskesmas and referenced hospital. The doctors and other health servants play role in disciplining patients to obey regulations of the public health center and hospital services. The service educates patients to behave and doing better health practices, and the health provider gets more social benefits.

The similar benefits may also be received by the health care providers. Dual roles in the structure (duality) of the patient and the doctor, other health servants awaken and support roles among each other and to receive each other social benefits. In particular, relationship between the role of patients and doctors takes place well and reproduce structuration.

The health care system fosters orderly the health behavioral pattern of patients. This also improves orderly to health service behaviors. Changes in the health behavior of patients increase the patient's awareness to understand the important health behavior due to the orders, recommendations, and advice of the doctors and other health servants in the Puskesmas and referenced hospitals.

The influence of changing (more orderly) patient's health behavior, in overtime supported by an orderly health care system, will contribute to improving condition of public health.

In conclusion, the relations of structuration of the BPJS Health Program and changing of health behavior in Surakarta Indonesia showed that there is a significant collaboration between The BPJS Office with Puskesmas and hospitals in Surakarta. Collaboration brings closer to social relations between patients and doctors and other health care providers. The relationship was constructed due to understanding, and obedience of the participants to the rules, in the forms of procedural rules and doctors' medicalization, of doctor's services treatment. The arrangements, orders, and prohibitions that function to protect patients, and the doctors, other services at the Puskesmas and the 
referenced hospitals adhered to the BPJS Health system operation.

Practices and activities to obtain health services are carried out repeatedly by BPPJS participating patients; doctors and other health care workers welcoming to the standard services according to the provisions of ethics and professional norms of doctors and other services. There are duality roles in structural agency between patients and health services. The patients and health care servants at Puskesmas and the referenced Hospitals reinforce social relationships and produce mutual benefits and benefits among others; Giddens calls it is form of structuration that affect the continuity of good patterns of social behavior and practices especially health behavior; and these have a positive effect to the community and public health. So, there is relation between structuration of the BPJS Health Program and changing of health behavior in Surakarta Indonesia.

\section{AUTHOR CONTRIBUTION}

RB Soemanto and TA Gutama were the authors of this study. They implemented the study, collected the data, formulated articles of the study and processed data.

\section{CONFLICT OF INTEREST}

There is no conflict of interest in this study.

\section{FUNDING AND SPONSORSHIP}

The source of funds in this study used grants from the Central Agency for the Improvement of Health Human Resources Quality (BPPSDMK) Ministry of Health of the Republic of Indonesia.

\section{ACKNOWLEDGEMENT}

The authors would like to thank the Health Office and Boyolali Health Center for allowing this study to be carried out.
REFERENCE

Elsa F (2014). Kepuasan Pasien BPJS (Badan Penyelenggara Jaminan Sosial) terhadap Pelayanan di Unit Rawat Jalan Rumah Sakit Permata Medika Semarang. Retrieved from http://eprints.dinus.ac.id/6709/1/jurnal_13951.pdf

Giddens A (1984). The Constitution of Society: Outline of the Theory of Structuration. Cambridge: Polity Press.

Kuswarno E (2009). Metode penelitian komunikasi fenomenologi, konsepsi, pedoman, dan contoh penelitiannya. Bandung: Penerbit Widya

Marshall, Roosman (2009). Metodepenelitian komunikasi fenomenologi, konsepsi, pedoman, dan contoh penelitiannya (dalam Engkus Kuswarno), Bandung: Penerbit Widya.

Mead H, Blumer H (2002). Teorisosiologi modern. (Eds). George Ritzer, University of Maryland - Douglas J. Goodman, University of Puget Sound.

Parsons T (2002). Teori sosiologi modern. (Eds). George Ritzer, University of Maryland-Douglas J. Goodman, University of Puget Sound

Rumengan D, et al. (2015). Faktor-faktor yang berhubungan dengan pemanfaatan pelayanan kesehatan pada peserta bpjs kesehatan di Puskesmas Paniki Bawah Kecamatan Mapanget Kota Manado. Manado: JIKMU, 5(1).

Septia A (2015). Respon kepuasan pasien pengguna BPJS kesehatan terhadap pelayanan kesehatan di Puskesmas Pekanbaru. Jom Fisip, 2(2).

SilviaB, Lindawati K (2017). Pengaruh kualitas pelayanan BPJS kesehatan terhadap kepuasan pengguna perspektif dokter Rumah Sakit Hermina Bogor. Jurnal Riset Manajemen dan Bisnis 2(1): 1-12. 